DOI: https://doi.org/10.31933/jemsi.v2i5

Received: 16 April 2021, Revised: 15 Mei 2021, Publish: 4 Juli 2021

JEMSI
DINASTI
REVI W

\title{
MODEL KINERJA KARYAWAN : KEPEMIMPINAN, BUDAYA ORGANISASI DAN KOMPETENSI (PENDEKATAN KONSEP MANAJEMEN STRATEGIK)
}

Desi Tya Astuti

Program Pascasarjana Universitas Mercu Buana, Jurusan Manajemen, Desitya27@gmail.com

\begin{abstract}
Abstrak: Tujuan dari penulisan artikel ini adalah untuk menjelaskan suatu kerangka kerja konseptual yang menggambarkan hubungan variabel-variabel kepemimpinan, budaya, kompetensi, dan kinerja. Artikel ini mempresentasikan beberapa konsep teori dari Budaya Organisasi, Kepemimpinan, dan Manajemen Strategik. Akhirnya beberapa tujuan penelitian yang mengamati tentang hubungan variabel-variabel kepemimpinan, budaya, kompetensi dan kinerja sangatlah diharapkan untuk mengembangkan tujuan penelitian.
\end{abstract}

Kata Kunci: Kinerja, Kepemimpinan, Budaya, Kompetensi

\section{PENDAHULUAN}

\section{Latar Belakang Masalah}

Keberhasilan keseluruhan dari lembaga dalam mencapai tujuan strategis sangat bergantung pada tingkat kinerja pegawai pegawai. Kinerja itu sendiri adalah hasi kerja secara kualitas dan kuantitas yang dicapai oleh seseorang pegawai dalam melaksanakan tugasnya, sesuai dengan tanggung jawab yang diberikan kepadanya Mangkunegara (2011). Sedangkan menurut Rivai dan Sagala (2013) kinerja adalah fungsi dari motivasi dan kemampuan untuk menyelesaikan tugas atau pekerjaan seseorang yang sepatutnya memiliki derajat kesediaan dan tingkat kemampuan tertentu. Sehingga dapat dinyatakan salah satu cara untuk membuat orang suka bekerja keras dan meningkatkan kinerja pegawainya adalah dengan memotivasi mereka.

Faktor yang mempengaruhi kinerja pegawai adalah kepemimpinan. Pemimpin yang kompeten menjadi lebih mudah menggiring pegawai untuk memiliki kinerja yang 
akan sangat mendukung tujuan organisasi. Kepemimpinan ini merujuk pada karakteristik yang mendasari perilaku yang menggambarkan motif karakteristik pribadi, konsep diri, nilai -nilai pengetahuan atau keahlian yang dibawa seseorang yang berkinerja unggul di tepat kerja. Kompetensi berhubungan dengan apa yang dilakukan orang ditempat kerja pada bebrabai tingkatan dan memeperinci standar masing-masing tingkatan, mengidentifikasi karateristik, pengetahuan dan keterampilan yang diperlukan oleh individual yang memungkinkan menjalankan tugas dan tanggung jawab secara efektif sehingga mencapai standar kualitas profesional dalam bekerja dan mencakup semua aspek catatan manajemen kinerja, keterampilan dan pengetahuan tertentu, sikap, komunikasi, aplikasi dan pengembangan.

Terdapat 3 jenis kompetensi yaitu:

1) Core competencies merupakan kompetensi inti tang dihubungkan dengan strategi organisasi sehingga haus dimiliki oleh semua karyawan dalam organisasi.

2) Managerial competencies meruakan kompetensi yang mencerminkan aktivitas manajerial dan kinerja yang diperlukan dalam peran tertentu.

3) Functional competencies merupak kompetensi yang menjelaskan tentang kemampuan peran tertentu yang diperlukan dan biasanya dihubungkan dengan keterampilan profesional atau teknis.

Faktor lain yang turut mempengaruhi kinerja pegawai adalah budaya organisasi. Setiap organisasi memiliki budaya organisasi yang berbeda-beda sehingga perbedaan budaya organisasi akan mempengaruhi pegawai dalam perilaku kerjanya. Budaya organisasi juga menjadi penentu dalam suatu organisasi terhadap pemimpin memnentukan sikap dan arah dalam memimpin. Karena seperti diketahui budaya organisasi merupakan filosofi dasar organisasi yang menutut keyakina, norma, dan nilainilai tersebut menjadi pegangan semua sumber daya manusia dalam organisasi dalam melaksanakan kinerjanya. Budaya organisasi dapat juga dinyatakan sebagai suatu sistem dari makna bersama yang dianut oleh para anggotanya yang memebedakan organisasi dengan organisai lainnya. 
Kemudian selain beberapa hal yang telah disebutkan diatas, hal lainnya adalah kompetensi yang dimiliki pegawai tersebut yang harus mampu mendukung pelaksanaan strategi organisasi dan mampu mendukung setiap perubahan yang dilakukan pimpinan untuk menghadapi perubahan lingkungan yang terjadi. Kompetensi adalah suatu kemampuan untuk melaksanakan atau melakukan suatu pekerjaan atau tugas yang dilandasi atas keterampilan dan pengetahuan serta didukung oleh sikap kerja yang dituntut oleh pekerjaan tersebut. Untuk itu, kompetensi individu berupa keahlian, kemampuan dan pengetahuan harus dikembangkan. Oleh karena itu, organisasi perlu melakukan upaya pengembangan kompetensi secara sistematis.

Artikel ini membahas pengaruh kepemimpinan dan budaya terhadap motivasi dan kinerja karyawan melalui pendekatan konsep manajemen strategik studi literature Manajemen Sumber Daya Manusia.

\section{Rumusan Masalah}

Berdasarkan latar belakang akan di rumuskan masalah yang akan di bahas pada artikel literature review agar lebih focus pada kajian pustaka dan hasil serta pembahasan nanti, yaitu:

1. Apakah kepemimpinan memiliki hubungan dan berpengaruh terhadap kinerja karyawan?

2. Apakah budaya organisasi memiliki hubungan dan berpengaruh terhadap kinerja karyawan?

3. Apakah kompetensi memiliki hubungan dan berpengaruh terhadap kinerja karyawan?

\section{KAJIAN TEORI}

Kinerja Karyawan

Menurut (Robbins, 2003: 27) istlah lain dari kinerja karyawan adalah human output yang dapat diukur dari productivity, absence, turnover, citizenship, dan satisfaction. Kinerja itu sendiri adalah hasi kerja secara kualitas dan kuantitas yang dicapi oleh seseorang pegawai dalam melaksanakan tugasnya, sesuai dengan tanggung jawab yang diberikan kepadanya (Mangkunegara, 2011). 
Sedangkan menurut Wibowo (2016) kinerja adalah tentang melakukan pekerjaan dan hasil yang dicapai dari pekerjaan tersebut. Kinerja adalah tentang apa yang dikerjakan dan bagaimana cara mengerjakannya. Sehingga dapat dinyatakan salah satu cara untuk membuat orang suka bekerja keras dan meningkatkan kinerja pegawainya adalah dengan memotivasi mereka. Organisasi di dunia global yang dinamis ini terus berusaha mengembangkan dan memotivasi pegawai mereka untuk membantu mencapai kinerja pegawai yang ditingkatkan dengan berbagai aplikasi dan praktek Sumber Daya Manusia. Motivasi diperlukan sebagai salah satu indikator kinerja pegawai pegawai. Pegawai dengan motivasi yang tinggi dapat diharapkan akan memperlihatkan kinerja pegawai yang optimal. Seseorang yang bergabung dalam organisasi pada sebuah perusahaan dituntut motivasi dalam dirinya.

Secara teori banyak faktor yang dapat mempengaruhi kinerja, menurut Mangkunegara (2011) menyatakan bahwa faktor-faktor yang dapat mempengaruhi kinerja adalah:

a) Faktor kemampuan (ability. Secara psikologis, kemampuan (ability) pegawai terdiri dari kemampuan potensi (IQ) dan kemampuan reality (knowledge + skill). Artinya pegawai yang memiliki IQ di atas rata-rata (IQ 110-120) dengan pendidikan yang memadai untuk jabatannya dan terampil dalam mengerjakan pekerjaan sehari-hari, maka ia akan lebih mudah mencapai kinerja yang diharapkan. Oleh karena itu, pegawai perlu ditempatkan pada pekerjaan yang sesuai dengan keahliannya.

b) Faktor motivasi. Motivasi terbentuk dari sikap (attitude) seseorang pegawai dalam menghadapi situasi (situation) kerja. Motivasi merupakan kondisi yang menggerakkan diri pegawai yang terarah untuk mencapai tujuan organisasi (tujuan kerja). Sikap mental merupakan kondisi mental yang mendorong diri pegawai untuk berusaha mencapai prestasi kerja secara maksimal. Sikap mental pegawai harus sikap mental yang secara psikofisik (siap secara mental, fisik, tujuan,dan situasi), artinya seorang pegawai harus siap secara mental, mampu secara fisik, memahami secara fisik, memahami tujuan utama dari target kerja yang akan dicapai, mampu memanfaatkan, dan menciptakan situasi kerja. 
Sedangkan menurut Wirawan (2009) faktor-faktor yang mempengaruhi kinerja sumber daya manusia meliputi:

a) Faktor internal pegawai, yaitu faktor-faktor dari dalam diri pegawai yang merupakan faktor bawaan dari lahir dan faktor yang diperoleh ketika ia berkembang. Faktorfaktor bawaan, misalnya bakat, sifat pribadi, serta keadaan fisik dan kejiwaan. Sementara itu, faktor yang diperoleh, misalnya seperti pengetahuan, ketrampilan, etos kerja, pengalaman kerja, dan motivasi kerja.

b) Faktor lingkungan internal organisasi. Dalam melaksanakan tugasnya, pegawai memerlukan dukungan organisasi tempat ia bekerja. Dukungan tersebut sangat mempengaruhi tinggi rendahkan kinerja pegawai. Faktor internal organisasi antara lain teknologi robot, sistem kompensasi, iklim kerja, strategi organisasi, dukungan sumber daya yang diperlukan untuk melaksanakan pekerjaan, serta sistem manajemen dan kompensasi

c) Faktor lingkungan eksternal organisasi. Faktor-faktor lingkungan eksternal organisasi adalah keadaan, kejadian, atau situasi yang terjadi di lingkungan ekternal organisasi, misalnya krisis ekonomi.

Menurut Amstrong dan Baron (2000) secara lengkap menjelaskan bahwa empat faktor yang mempengaruhi kinerja yaitu: 1) faktor personal, meliputi ketrampilan individual, kompetensi, motivasi, dan komitmen, 2) faktor kepemimpinan, yaitu kualitas dari pemberian motivasi, bimbingan dan dorongan yang diberikan oleh pimpinan, 3) faktor sistem pekerjaan dan fasilitas yang diberikan oleh organisasi, dan 4) faktor situasional, meliputi perubahan dan penekanan dari factor internal dan eksternal.

Berdasarkan teori-teori yang telah dikemukakan maka penulis menyimpulkan bahwa kinerja karyawan merupakan hasil atau output baik secara kuantitas dan kualitas dari kegiatan produktivitas sehingga mampu terukur. Biasanya hasil ini dipernagruhi oleh beberapa faktor yaitu faktor internal dari dalam diri serta faktor internal dan faktor eksternal organisasi.

Kinerja Karyawan sudah banyak di teliti oleh peneliti sebelumnya diantaranya adalah : (Abd. Salam, 2017), (Tri Widodo, 2010), (Djoko, 2017), (Tinneke, 2015), (Andi, 
Hasniaty, 2017), (Enrico, 2013), (Reza, Rusli, Mahdani, 2016), (Fimce, Agusm Jacky, 2015), (Desi, Nasir, Sofyan, 2018).

\section{Kepemimpinan}

Menurut Dubrin (2001:3) bahwa kepemimpinan itu adalah kemampuan untuk menanamkan keyakinan dan memperoleh dukungan dari anggota organisasi untuk mencapai tujuan organisasi. Kepemimpinan itu ada pada diri pemimpin/manajer. Dari aspek karakteristik dibedakan antara karakteristik pemimpin (leader) dengan karkateristik manajer.

Luthans (2002:576) menegaskan bahwa karakteristik pemimpin di Abad XXI adalah: Innovates (menciptakan sesuatu yang baru); An original (asli dari pemimpin); Develops (mengembangkan); Focuses on people (terkonsentrasi pada manusia); Inspires trust (menghidupkan rasa percaya); Longrange perspective (memiliki prespektif jangka panjang); Asks what and why (ia menanyakan apa dan mengapa); Eye on the horizon (berpandangan sama pada sesamanya); Originates (memiliki keaslian); Challenges the Status quo (menentang kemapanan); Own person (mengakui tanggung jawab ada pada pemimpin); Does the right thing (mengerjakan yang benar). Pemimpin memiliki karakteristik selalu memiliki upaya untuk menciptakan hal yang baru (selalu berinovasi). Gagasan-gagasan yang dimiliki oleh pemimpin merupakan gagasan sendiri tidak meniru ataupun menjiplak. Pemimpin selalu berupaya untuk mengembangkan apa yang ia lakukan. Ia percaya pada bawahan, dan selalu menyalakan api kepercayaan pada anggota organisasi. Gagasannya memiliki prespektif jangka panjang. Ia bertanya pada bawahannya dengan pertanyaan apa dan mengapa?. Ia menentang status quo, ia tidak puas dengan apa yang ada. Ia bertanggung jawab atas apa yang dilakukan oleh bawahannya, dan ia mengerjakan yang benar.

Setiap pemimpin memiliki gaya kepemimpinan, ada kalanya pemimpin tidak memberi kesempatan pada bawahannya untuk bertanya ataupun minta penjelasan (Authoritarian), ada kalanya pemimpin memberi kesempatan bawahan untuk berdiskusi, bertanya (Democratic), dan ada kalanya pemimpin itu membiarkan kondisi yang ada terserah pada bawahan (Laissez -fair) (The Iowa Leadershi Study) (Luthans, 2002). 
Jacobs dan Jacques (dalam Dias, 2008) menyatakan bahwa kepemimpinan adalah sebuah proses memberi penerangan atau penjelasan sehingga bawahan benar-benar paham dan termotivasi untuk mengikuti keinginan pimpinan. Selain pemberian penerangan perlu juga pemberian tanggung jawab, pendelegasian kewenangan, dan pengembangan.

Hal ini senada dengan penelitian Mitzberg (Covey, 2005) menyatakan bahwa bawahan akan termotivasi untuk bekerja lebih baik apa bila ada upaya-upaya pemberdayaan. Menurut Gibson (2008) keberhasilan perusahaan sangat ditentukan oleh efektivitas keberhasilan pemimpin dan pegawai dari semua divisi dalam perusahaan. Pendapat Gibson ini mempunyai konsekuensi adanya suatu tuntutan kepada perusahaan untuk lebih memperhatikan aspek-aspek kritis yang merupakan faktor penentu keberhasilan kinerja pegawai seorang pemimpin, sehingga pegawai dapat meraih Kinerja pegawai Pegawai.

Berdasarkan teori-teori diatas maka penulis dapat menyimpulkan kepemimpinan adalah proses dimana individu memengaruhi sekelompok individu untuk mencapai tujuan bersama. Kepemimpinan mencakup pengaruh. Kepemimpinan peduli dengan cara pemimpin memengaruhi pengikutnya. Pengaruh adalah elemen penting kepemimpinan. Tanpa pengaruh, kepemimpinan tidak eksis.

Kepemimpinan sudah banyak di teliti oleh peneliti sebelumnya diantaranya adalah : (Abd. Salam, 2017), (Tri Widodo, 2010), (Djoko, 2017), (Tinneke, 2015), (Andi, Hasniaty, 2017), (Enrico, 2013), (Reza, Rusli, Mahdani, 2016), (Fimce, Agusm Jacky, 2015), (Desi, Nasir, Sofyan, 2018).

\section{Budaya Organisasi}

Menurut Wibowo (2010) budaya organisasi adalah filosofi dasar organisasi yang memuat keyakinan, norma-norma, dan nilai-nilai tersebut menjadi pegangan semua sumber daya manusia dalam organisasi dalam melaksanakan kinerjanya. Budaya organisasi dapat juga dinyatakan sebagai suatu sistem dari makna/arti bersama yang dianut oleh para anggotanya yang membedakan organisasi dengan organisasi lainnya (Robbins, 2012). 
Definisi budaya organisasi menurut Ardana, dkk (2009:166) adalah sebagai berikut :

1. Suatu persepsi bersama yang dianut oleh suatu organisasi.

2. Cara berpikir dan melakukan sesuatu yang mentradisi yang dianut bersama oleh semua organisasi, dan para anggota baru harus mempelajari atau paling sedikit menerimanya sebagaian agar mereka diterima sebagai bagian dari organisasi itu.

3. Himpunan dari kepercayaan, harapan dan nilai yang dianut bersama oleh anggota organisasi dan diwariskan ke generasi berikutnya.

4. Makna dan keyakinan bersama yang dianut oleh para organisasi yang menentukan cara bertindak.

Budaya organisasi dapat menjadi instrumen keunggulan kompetitif yang utama, yaitu bila budaya organisasi mendukung strategi organisasi, dan bila budaya organisasi dapat menjawab atau mengatasi tantangan lingkungan dengan cepat dan tepat. Budaya organisasi akan mempengaruhi semua aspek organisasi dan perilaku anggota organisasi yang kemudian menentukan kinerja anggota dan kinerja organisasi.

Budaya organisasi telah di teliti oleh peneliti sebelumnya diantaranya adalah (Abd. Salam, 2017), (Tri Widodo, 2010), (Djoko, 2017), (Tinneke, 2015), (Andi, Hasniaty, 2017), (Enrico, 2013), (Reza, Rusli, Mahdani, 2016), (Fimce, Agusm Jacky, 2015), (Dewie, 2010).

\section{Kompetensi}

Kompetensi adalah suatu kemampuan untuk melaksanakan atau melakukan suatu pekerjaan atau tugas yang dilandasi atas keterampilan dan pengetahuan serta didukung oleh sikap kerja yang dituntut oleh pekerjaan tersebut. Kompetensi sebagai kemampuan seseorang untuk menghasilkan pada tingkat yang memuaskan di tempat kerja, juga menunjukkan karakteristik pengetahuan dan keterampilan yang dimiliki atau dibutuhkan oleh setiap individu yang memampukan mereka untuk melakukan tugas dan tanggung jawab mereka secara efektif dan meningkatkan standar kualitas professional dalam pekerjaan. Ada dua istilah yang muncul dari dua aliran yang berbeda tentang konsep 
kesesuaian dalam pekerjaan. Istilah tersebut adalah "Competency" (kompetensi) yaitu deskripsi mengenai perilaku, dan "Competence" (kecakapan) yang merupakan deskripsi tugas atau hasil pekerjaan Palan (2007).

Konsep kompetensi berawal dari artikel David McClelland yang mengegerkan, "Testing for competence rather than intelligence". Artikel tersebut meluncurkan gerakan kompetensi dalam psikologi industrial. David McClelland menyimpulkan, berdasarkan hasil penelitian, bahwa tes kecakapan akademis tradisional dan pengetahuan isi, serta nilai dan ijazah sekolah; (1) tidak dapat memprediksi keberhasilan dipekerjaan/kehidupan, (2) biasanya bias terhadap masyarakat yang sosial ekonomi rendah. Walau perbedaan arti kedua istilah tersebut diterima secara umum, namun penggunaannya masih sering dipertukarkan, yang menyebabkan setiap orang memiliki pengertian yang berbeda-beda.

Umumnya orang menggunakan istilah kompetensi dan sejenisnya menciptakan pengertian sendiri sesuai dengan kepentingannya. Komentar Zamkee (1982) yang dikutip oleh Palan (2007:6) mengatakan bahwa "Kompetensi (competence), model kompetensi dan pelatihan berbasis kompetensi merupakan kata yang bisa diartikan beragam mengikuti pendefinisiannya. Perbedaan makna tersebut bukan berasal dari kebodohan atau ketamakan pasar, tapi dari beberapa prosedur mendasar dan perbedaan filosofis diantara mereka yang berlomba untuk mendefinisikan dan membentuk konsep tersebut dan menetapkan model bagi kita yang akan menggunakan kompetensi dalam upaya sehari-hari.

Kompetensi telah di teliti oleh peneliti sebelumnya diantaranya adalah (Reza, Rusli, Mahdani, 2016) dan (Desi, Nasir, Sofyan, 2018).

\section{Conceptual Framework}

Berdasarkan Kajian teori dan hubungan antar variabel maka model atau Conceptual Framework artikel ini dalam rangka menbagunan hipotesis adalah sebagai berikut: 


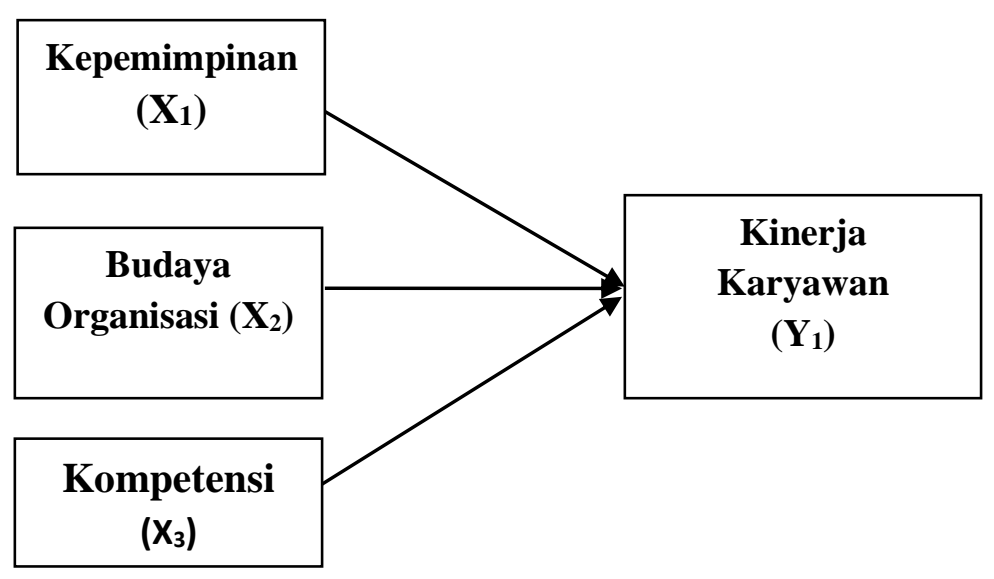

\section{METODE PENULISAN}

Metode penulisan artikel ilmiah ini adalah dengan metode kualitatif dan studi literature atau Library Research. Mengkaji Buku-buku literature sesuai dengan teori yang di bahas khusunya di lingkup Manajemen Sumber Daya Manusia (MSDM). Disamping itu menganalisis artikel-artikel ilmiah yang bereputasi dan juga artikel ilmiah dari jurnal yang belum bereputasi. Semua artikel ilmiah yang di citasi bersumber dari Scholar Google.

Dalam penelitian kualitatif, kajian pustaka harus digunakan secara konsisten dengan asumsi-asumsi metodologis. Artinya harus digunakan secara induktif sehingga tidak mengarahkan pertanyaan-pertanyaan yang diajukan oleh peneliti. Salah satu alasan utama untuk melakukan penelitian kualitatif yaitu bahwa penelitian tersebut bersifat eksploratif, (Ali \& Limakrisna, 2013).

Selanjutnya dibahas secara mendalam pada bagian yang berjudul" Pustaka Terkait" (Related Literature) atau Kajian pustaka("Review of Literature"), sebagai dasar perumusan hipotesis dan selanjutnya akan menjadi dasar untuk melakukan perbandingan dengan hasil atau temuan-temuan yang terungkap dalam penelitian, (Ali \& Limakrisna, 2013).

\section{PEMBAHASAN}

Artikel ini menganalis dan membahas tentang variabel-variabel Manajemen Sumber Daya Manusia (MSDM) yaitu: Kinerja Karyawan, Kepemimpinan, Budaya Organisasi dan kompetensi. Dimana Motivasi, Kepemimpinan, dan Budaya Organisasi 
berpengaruh terhadap Kinerja Karyawan. Riset dan artikel terdahulu dan relevan dengan artikel ini di antarnya adalah:

\section{1) Kepemimpinan berpengaruh terhadap Kinerja Karyawan}

Kepemimpinan berpengaruh secara tidak langsung terhadap tingkat prestasi kerja karyawan melalui variabel Tingkat Iklim Organisasi, artinya pemimpin memiliki peran membentuk iklim organisasi yang lebih kondusif, dari iklim yang lebih kondusif itu terbentuk-lah tingkat kinerja kerja karyawan yang lebih baik.

Teori ini sejalan dengan penelitia yang dilakukan oleh (Tri Widodo, 2010), (Djoko Setyo Widodo, 2017) dan (Andi Ratna Sari Dewi, 2017) yang mengemukakan bahwa gaya kepemimpinan berpengaruh positif dan signifikan terhadap kinerja pegawai.

\section{2) Budaya Organisasi berpengaruh terhadap Kinerja Karyawan}

Budaya Organisasi berpengaruh terhadap Kinerja Karyawan, ini diperkuat oleh hasil penelitian (Tinekke E.M. Sumual, 2015), (Enrico Maramis, 2013) (Reza, Rusli dan Mahdani, 2016).

Budaya organisasi merupakan kumpulan kepercayaan, harapan, dan nilai nilai yang dianut bersama oleh anggota organisasi dan diwariskan dari satu generasi ke generasi berikutnya. Budaya organisasi memiliki peran untuk mengubah sikap dan juga perilaku sumber daya manusia atau karyawan yang ada agar dapat meningkatkan produktivitas kerja untuk menghadapi berbagai tantangan di masa yang akan datang.

Manfaat budaya organisasi diantaranya adalah : meningkatkan jiwa gotong royong, meningkatkan kebersamaan, saling terbuka satu sama lain, membangun komunikasi yang lebih baik, meningkatkan produktivitas kerja, dan tanggap dengan perkembangan dunia luar. Sehingga budaya organisasi berfungsi mengubah sikap dan perilaku karyawan, agar dapat meningkatkan produktivitas kerjanya, jadi semakin baik budaya organisasi maka semakin tinggi kinerja karyawan.

\section{3) Kompetensi berpengaruh terhadap Kinerja Karyawan}

Kompetensi merujuk kepada karakteristik yang mendasari perilaku yang menggambarkan motif, karakteristik pribadi (ciri khas), konsep diri, nilai-nilai, 
pengetahuan atau keahlian yang dibawa seseorang yang bekinerja unggul di tempat kerja.

Kompetensi berhubungan dengan apa yang dilakukan orang di tenpat kerja pada berbagai tingkatan dan memperinci standar masing-masing tingkatan, mengidentifikasi karakteristik, pengetahuan dan keterampilan yang diperlukan oleh individu yang memungkinkan menjalankan tugas dan tanggungjawab secara efektif.

Sehingga ketika individu memiliki kompetensi yang berupa standar keterampilan dan pengetahuan tertentu, sikap, komunikasi, aplikasi dan pengembangan untuk mencapai standar kualitas profesional dalam bekerja dan mencakup semua aspek catatan manajemen kinerja karyawan

Teori ini sejalan dengan penelitia yang dilakukan oleh (Reza, Rusli, Mahdani, 2016) dan (Desi, Nasir, Sofyan, 2018). yang mengemukakan bahwa kompetensi berpengaruh positif dan signifikan terhadap kinerja pegawai.

Kepemimpinan $\left(\mathrm{X}_{1}\right)$, budaya organisasi $\left(\mathrm{X}_{2}\right)$ dan Kompetensi berpengaruh terhadap kinerja karyawan (Y).

Selain dari tiga variabel exogen ini yang mempengaruhi kinerja karyawan(y), masih banyak variabel lain yang mempengaruhinya diantaranya adalah:

1) Kompensasi (X4) : (Djoko Setyo Widodo, 2017),

2) Komitmen Organisasi (X5) : (Andi Ratna Sari Dewi, 2017)

3) Inovasi Pemimpin (X6) : (Fimce, Agus, Jacky, 2015)

\section{KESIMPULAN DAN SARAN}

Kesimpulan

Berdasarkan pembahasan, maka dapat disimpulkan untuk membangun suatu hipotesis guna untuk riset selanjutnya seperti di bawah ini:

1) Gaya Kepemimpinan (x1) berpengaruh terhadap Kinerja Karyawan (y).

2) Budaya Organisasi (x2) berpengaruh terhadap Kinerja Karyawan (y).

3) Kompetensi berpengaruh terhadap Kinerja Karyawan (y).

\section{Saran}

Bersdasarkan Kesimpulan di atas, maka saran pada artikel ini adalah bahwa masih banyak factor lain yang mempengaruhi Kinerja Karyawan atau Kinerja Pegawai pada semua tipe dan level organisasi, oleh karena itu masih di perlukan kajian yang lebih lanjut untuk melengkapi faktor-faktor lain apa sajakah yang dapat memepengaruhi Kinerja. 
Faktor lain tersebut seperti Kompensasi (X4), Komitmen Organisasi (X5) dan Inovasi Pemimpin (X6).

\section{DAFTAR PUSTAKA}

Ali, H., Limakrisna, N., \& Jamaluddin, S. (2016). Model of customer satisfaction: The empirical study at Bri in Jambi. International Journal of Applied Business and Economic Research.

Antoni Feri, 2006. Pengaruh Gaya Kepemimpinan Orientasi Tugas dan Orientasi Hubungan terhadap Motivasi Kerja dan Dampaknya pada Prestasi Kerja Pegawai Pengadilan Tinggi Tata Usaha Negara Surabaya, Tesis Universitas 17 Agustus Surabaya.

Ardana Komang, Ni Wayan Mujiati, Anak agung Ayu Sriathi, 2009. Perilaku Keorganisasian. Edisi 2. Jakarta: Penerbit Graha Baru

Covey R Sthepen. 2005. The 8th Habit. Jakarta: PT Gramedia Pustaka Utama.

Desi Saputra, Nasir, Sofyan. (2018). Pengaruh Kompetensi, Gaya Kepemimpinan, Budaya Kerja Dan Lingkungan Kerjaterhadap Kepuasan Kerja Pegawai Dan Dampaknya Terhadap Kinerja Pegawai Kantor Kementerian Agama Kabupaten Aceh Barat. Jurnal Magister Manajemen

Dewi, Andi Ratna S. (2017). Pengaruh Gaya Kepemimpinan, Budaya Organisasi Dan

Komitmen Organisasi Terhadap Kinerja Pegawai Dinas Pertanian Kabupaten Mamuju. JBMI

Gibson. 2008. Manajemen Sumber Daya Manusia. Edisi Keempat. Jakarta: Erlangga.

Hasibuan, Malayu S.P. 2013. Manajemen Sumber Daya Manusia. Jakarta: Bumi Aksara.

Luthans, Fred. 2002. Organizational Behavior, Ninth Edition. Singapore: McGraw- Hill International Editions.

Mangkunegara Anwar Prabu, 2005. Manajemen Sumber Daya Manusia Perusahaan, Cetakan Keenam, PT. Remaja Rosdakarya, Bandung.

Mangkunegara Anwar Prabu, 2005. Perilaku dan Budaya Organisasi, Cetakan Pertama, PT. Refika Aditama, Bandung.

Mangkunegara, A.A. Anwar P. 2011. Manajemen Sumber Daya Manusia. Perusahaan. Bandung: PT. Remaja Rosdakarya.

Maramis, Enrico. (2013). Kepemimpinan, Budaya Organisasi, Dan Motivasi Pengaruhnya Terhadap Kinerja Karyawan Pada Pt. Bank Tabungan Negara (Persero) Cabang Manado. Jurnal EMBA

Masambe, Fimce. Agus, Jacky. (2015). Pengaruh Gaya Kepemimpinan, Budaya Organisasi Dan Inovasi Pemimpin Terhadap Kinerja Karyawan Daihatsu Kharisma Manado. Jurnal EMBA

Palan, R. 2007. Competency Management: Teknis Mengimplementasikan Manajemen SDM Berbasis Kompetensi Untuk Meningkatkan Daya Saing Organisasi. Jakarta: PPM. 
Robbins, S.P. 2003. Organizational Behavior, Tenth Edition. Singapore: Prentice Hall.

Robbins, S.P. 2012. Perilaku Organisasi. Jakarta : Indeks.

Salam, Abd. (2017). Hubungan Kepemimpinan, Budaya, Strategi, Dan Kinerja: Suatu Pendekatan Konsep. Majalah Manajemen Dan Bisnis Ganesha.

Sumual, Tinneke E.M. (2015). Pengaruh Kompetensi Kepemimpinan, Budaya Organisasi terhadap Kinerja Pegawai di Universitas Negeri Manado. Pusat Penerbitan Universitas (P2U) LPPM Unisba.

Wibowo. 2010. Budaya Organisasi. Rajawali Pers: Jakarta.

Widodo, Djoko Setyo. (2017). Pengaruh Budaya Organisasi, Kepemimpinan Dan Kompensasi Melalui Motivasi Kerja Terhadap Kinerja Pegawai. Jurnal Manajemen Motivasi.

Widodo, Tri. (2010). Pengaruh Lingkungan Kerja, Budaya Organisasi, Kepemimpinan Terhadap Kinerja (Studi Pada Pegawai Kecamatan Sidorejo Kota Salatiga). Among Makarti.

Wijayanti, Dewie Tri. (2010). Faktor-Faktor yang Mempengaruhi Manajemen Strategik pada Organisasi Non Profit (Studi Manajemen Strategik pada Dinas Propinsi Jawa Timur). Jurnal Manajemen dan Kewirausahaan

Zarvedi, Reza, Rusli Yusuf, Mahdani Ibrahim. (2016). Pengaruh Kepemimpinan, Budaya Organisasi Dan Kompetensi Terhadap Kinerja Pegawai Serta Implikasinya Pada Kinerja Sekretariat Kabupaten Pidie Jaya. Jurnal Perspektif Ekonomi Darussalam. 